\title{
Experiment Investigation on a Solar Asisted Heat Pump Dryer for Chili
}

\author{
Bùi Quang Huy ${ }^{1, ~ *, ~ L e ̂ ~ M i n h ~ N h u ̣ t ' ~}{ }^{2, *}$ \\ ${ }^{1}$ Faculty of Electrical and Electronic Engineering Technology, Vinh Long University of Technology and Education,Vinh Long, Vietnam \\ ${ }^{2}$ Department of Thermal Engineering, Faculty of Vehicle and Energy Engineering, Ho Chi Minh City University of Technology and \\ Education, Ho Chi Minh, Vietnam
}

Email address:

huybq@vlute.edu.vn(B. Q.Huy),nhutlm@hcmute.edu.vn(L. M. Nhựt)

${ }^{*}$ Corresponding author

\section{To cite this article:}

Bùi Quang Huy, Lê Minh Nhựt. Experiment Investigation on a Solar Asisted Heat Pump Dryer for Chili. International Journal of Energy and Environmental Science. Vol. 3, No. 1, 2018, pp. 37-44. doi: 10.11648/j.ijees.20180301.14

Received: March 9, 2018; Accepted: March 24, 2018; Published: April 12, 2018

\begin{abstract}
The aim of this research is to evaluate the performance of solar assisted heat pump dryer for chilli. The experiments were carried out on three types different of days such as clear day, intermittent cloud sky day and overcast sky day. The experimental results show that the useful heat gain of solar collectors for drying chili of the clear day, intermittent cloud sky day and overcast sky day are $14.5 \mathrm{kWh} ; 8.91 \mathrm{kWh}$ and $0 \mathrm{kWh}$, respectively, and the corresponding energy consumptions of solar- assisted heat pump dryer are $19.2 \mathrm{kWh}, 21.4 \mathrm{kWh}$ and $26.1 \mathrm{kWh}$, respectively. The coefficients of performance (COP) in the three cases are $3.45,3.46$, and 3.51 , respectively.
\end{abstract}

Keywords: Drying, Flat Plate Collector, Heat Pump, Solar Radiation, The Useful Heat Gain, Coefficient of Performance

\section{Introduction}

In the agricultural products, chili is a relatively valuable export item. For export, chilli is usually dried. In our country, popular method to dry chili is drying directly in sunlight. However, this method is easy to discolor it and makes it failing to meet export standards. In addition, sun exposure for 10-20 days shall enable for chili's pathogens to continue to develop during sun exposure and to degrade its quality. So, heat-based drying methods powered by electricity or fuel are considered as the solutions to save time while maintaining the quality of the product. In particular, there are more and more studies on application of heat pump in drying because it have the potential to achieve higher energy savings as well as to limit pollution in comparison to conventional electric or fuel-based drying methods.

In addition, using renewable energy sources such as solar energy is also considered in the context of the increasingly exhausted fossil fuel sources, environmental protection and anti-greenhouse effect. From such idea, there are many studies in the world that combine heat pump and solar energy for use in the field of drying. Fudholi et al. [1] have investigated the economic and technical feasibility of four solar drying models using collectors. A study was conducted by M. Yahya et al. [2] to compare the efficiency of a solar drying system with a combination of heat pump and solarpowered drying system in a cassava drying experiment. It has been shown that the method of heat-pump drying combined with solar energy had a faster drying rate and higher thermal efficiency compared to solar drying methods. A mathematical model was developed by Mohamed Ayub Hossain et al. [3] to evaluate the efficiency of a heat pump dryer in drying pineapple. A combination of heat pump and solar-powered drying system was developed by Dahigh et al [4] for drying agricultural and seafood products. This author showed the potential of using a heat pump dryer combined with solar energy to dry food or biologically active products. Vietnam has a huge potential for solar energy, with an average of 2,000 to 2,500 hours of sunshine a year, ranging from 8 degrees north to 23 degrees north latitude, and relatively high intensity of solar radiation. Total solar radiation is up to 100 to $175 \mathrm{kcal} / \mathrm{cm}^{2} /$ year. Therefore, the use of solar energy combined heat pump system will bring great economic efficiency. This article presents the results of a study on the efficiency of a chili dryer using a combination of heat pump and solar energy to evaluate the applicability of this drying method in climatic conditions of Vietnam. 


\section{Method}

\subsection{The Mathematical Model}

The performance of the solar- assisted heat pump dryer system was calculated using the following equation is taken from the calculation by Yahya et al. [2] as follows

-The moisture content of chili on wet basis was calculated as follows:

$$
\mathrm{M}_{\mathrm{c}}=\frac{\mathrm{m}_{\mathrm{W}}}{\mathrm{m}_{\mathrm{W}}+\mathrm{m}_{\mathrm{d}}}
$$

Where $\mathrm{m}_{\mathrm{w}}$ is the mass of water $(\mathrm{kg})$, and $\mathrm{m}_{\mathrm{d}}$ is the mass of the bone dry $(\mathrm{kg})$.

-The thermal efficiency of the solar collector is the ratio of heat gained by the solar collector to the solar radiation incident on the plane of the collector. This parameter is calculated as follows:

$$
\eta_{\text {coll } .}=\frac{E_{\text {Ucoll }}}{E_{S}} \times 100 \%
$$

-Where $\mathrm{E}_{\mathrm{Ucoll}}$ : is the useful heat gain by the solar collector $(\mathrm{kW})$, and $\mathrm{E}_{\mathrm{S}}$ is the energy incident in the plane of the solar collector $(\mathrm{kW})$.

- The useful heat gain of the solar collector $\left(\mathrm{E}_{\mathrm{Ucoll}}\right)$ and energy incident in the plane of the solar collector $\left(E_{S}\right)$ are calculated using the following equations:

$$
\mathrm{E}_{\text {Ucoll }}=\dot{\mathrm{m}}_{\mathrm{air}} \mathrm{C}_{\text {Pair }}\left(\mathrm{T}_{\mathrm{o}, \text { coll }}-\mathrm{T}_{\mathrm{i}, \mathrm{coll}}\right)
$$

and

$$
\mathrm{E}_{\mathrm{S}}=\mathrm{I}_{\mathrm{t}} \mathrm{A}_{\mathrm{C}}
$$

-Where $\dot{m}_{\text {air }}$ is the air mass flow rate $(\mathrm{kg} / \mathrm{s})$, and $\mathrm{c}_{\text {pair }}$ is the specific heat of air $\left(\mathrm{J} / \mathrm{kg}^{\circ} \mathrm{C}\right) . \mathrm{T}_{\mathrm{i}, \text { cond }}$ and $\mathrm{T}_{\mathrm{o} \text {, cond }}$ are air temperatures at the inlet and outlet of the solar collector $\left({ }^{\circ} \mathrm{C}\right)$, respectively. $A_{c}$ is the area of the collector $\left(\mathrm{m}^{2}\right)$, and $I_{t}$ is the solar radiation incident on the collector $\left(\mathrm{W} / \mathrm{m}^{2}\right)$.

-The drying rate (DR) is the mass of water evaporated from the product per unit time and calculated as follows:

$$
\dot{\mathrm{m}}_{\text {Water }}=\frac{\mathrm{m}_{\text {Water }}}{\dot{\mathrm{t}}}
$$

-where $\mathrm{m}_{\text {water }}$ is the mass of water evaporated $(\mathrm{kg})$, and $\mathrm{t}$ is the drying time (s).

-The mass of water evaporated $\left(\mathrm{m}_{\text {water }}\right)$ from the wet product can be calculated as follows:

$$
\mathrm{m}_{\text {Water. }}=\frac{\mathrm{m}_{\mathrm{p}}\left(\mathrm{M}_{\mathrm{i}}-\mathrm{M}_{\mathrm{f}}\right)}{\left(100-\mathrm{M}_{\mathrm{f}}\right) \mathrm{t}}
$$

-where $m_{p}$ is the initial mass of the product $(\mathrm{kg}), \mathrm{M}_{\mathrm{i}}$ is the initial moisture content on wet basis (\%), and $\mathrm{M}_{\mathrm{f}}$ is the final moisture content on wet basis (\%).

-The coefficient of performance (COP) of the heat pump is the ratio of thermal energy released by the condenser to the electrical energy consumed by the compressor. This coefficient is calculated as follows:

$$
\mathrm{COP}=\frac{\mathrm{E}_{\mathrm{R}, \mathrm{Cond}}}{\mathrm{E}_{\mathrm{Comp}}}
$$

-where $E_{R, C o n d}$ is the thermal energy released by the condenser $(\mathrm{kW})$, and $\mathrm{E}_{\text {Comp }}$ is the electrical energy consumed by the compressor $(\mathrm{kW})$.

-The thermal energy released by the condenser can be calculated as follows:

$$
\mathrm{E}_{\mathrm{R}, \text { cond }}=\dot{\mathrm{m}}_{\mathrm{air}} \mathrm{C}_{\mathrm{Pair}}\left(\mathrm{T}_{\mathrm{o}, \text { cond }}-\mathrm{T}_{\mathrm{i}, \text { cond }}\right)
$$

-where $\mathrm{T}_{\mathrm{i} \text {,cond }}$ and $\mathrm{T}_{\mathrm{o} \text {,cond }}$ are the air temperatures at the inlet and outlet of the condenser $\left({ }^{\circ} \mathrm{C}\right)$, respectively.

-Specific moisture extraction rate (SMER) is the ratio of the moisture evaporated from the wet product to the energy input to the drying system. SMER is calculated as follows:

$$
\operatorname{SMER}=\frac{\dot{\mathrm{m}}_{\text {Water }}}{\mathrm{E}_{\text {input }}}
$$

-where $E_{\text {input }}$ is the energy input to the drying system $(\mathrm{kW})$.

-The energy input to the drying system can be calculated as follows:

$$
\mathrm{E}_{\text {input }}=\mathrm{E}_{\mathrm{s}}+\mathrm{E}_{\text {comp }}+\mathrm{E}_{\mathrm{b}}
$$

-where $E_{s}$ is the energy incident in the plane of the solar collector $(\mathrm{kW}), \mathrm{Ec}_{\mathrm{omp}}$ and $\mathrm{E}_{\mathrm{b}}$ are the electrical energies consumed by the compressor and blower $(\mathrm{kW})$, respectively.

-The electrical energy consumed by the compressor and blower is calculated using the following equation:

$$
\mathrm{E}_{\text {comp }} \text { and } \mathrm{E}_{\mathrm{b}}=\mathrm{VI} \cos \varphi
$$

-where $\mathrm{V}$ is the line voltage $(\mathrm{V}), \mathrm{I}$ is line current $(\mathrm{A})$, and $\cos \varphi$ is the power factor.

-Solar fractions (SFs) are the ratio of the useful heat gain or the energy extraction of heat from the solar collector to the energy available for drying. SFs of the solar-assisted heat pump drying system is calculated using the following equations;

$$
\mathrm{SF}_{\mathrm{SAHPD}}=\frac{\mathrm{E}_{\text {ucoll }}}{\mathrm{E}_{\mathrm{Ucoll}}+\mathrm{E}_{\text {comp }}+\mathrm{E}_{\mathrm{b}}}
$$

-where $\mathrm{SF}_{\mathrm{SAHPD}}$ is the SFs of the solar-assisted heat pump drying system, $\mathrm{E}_{\mathrm{Ucoll}}$ is the useful heat gain by the solar collector $(\mathrm{kW}), \mathrm{Ec}_{\mathrm{omp}}$ and $\mathrm{E}_{\mathrm{b}}$ are the electrical energies consumed by the compressor and blower $(\mathrm{kW})$, respectively.

\subsection{Development of Experimental Model of the Solar- Assisted Heat Pump Dryer}

- The solar-assisted heat pump dryer system designed and manufactured by Vinh Long University of Technology Education has a diagram of the principle and the actual shape showed in Figure 1, Figure 2 and 3. 
This system consists of a flat plate collector, a heat pump, a drying chamber, exhausted fan and pipes covered by $10-$ $\mathrm{mm}$ layer of polyurethane insulation. Flat plate collector is $1 \mathrm{~m} \times 2 \mathrm{~m} \times 10 \mathrm{~cm}$ in dimension. It is made of chromium plated and black copper tubes and plates and protected by 6$\mathrm{mm}$ reinforced glass panels. The drying chamber is of $38 \mathrm{~cm}$ $\mathrm{x} 38 \mathrm{~cm} \times 40 \mathrm{~cm}$ in dimension and is divided into 5 compartments for 5 trays of chili. Heat pump includes a $750 \mathrm{~W}$ compressor, expansion valve, main and auxiliary condenser, evaporator, and two $38 \mathrm{~W}$ exhaust fans. The temperature and humidity of the air at the inlet and outlet of the solar collector, heat pump and drying chamber are recorded by the DHT 22 temperature-humidity sensors located on the air flow. The temperature in the drying chamber is set and controlled by the ARDUINO processor combined with three additional heating resistance bars with a capacity of $110 \mathrm{~W}$ for each. When the radiation on the collector is large enough to generate useful energy, the sensors will record the value and transmit it to the Arduino processor to turn off the resistors to save power. Power consumption is measured by the electricity meter. The solar radiation is measured by a Tenmars TM-207 radiation meter with a tolerance of $+/-5 \%$. Speed and flow of the drying agent are determined by a Lutron AM4216 flow meter with a tolerance of $\pm 2 \%$. Ambient temperature and humidity are determined by Fluke 971 temperature humidity meter with a tolerance of $\pm 0.5^{\circ} \mathrm{C}$ and $\pm 2.5 \% \mathrm{RH}$. Weight change of chili is measured by an electronic scale with a tolerance of \pm 0.01 .

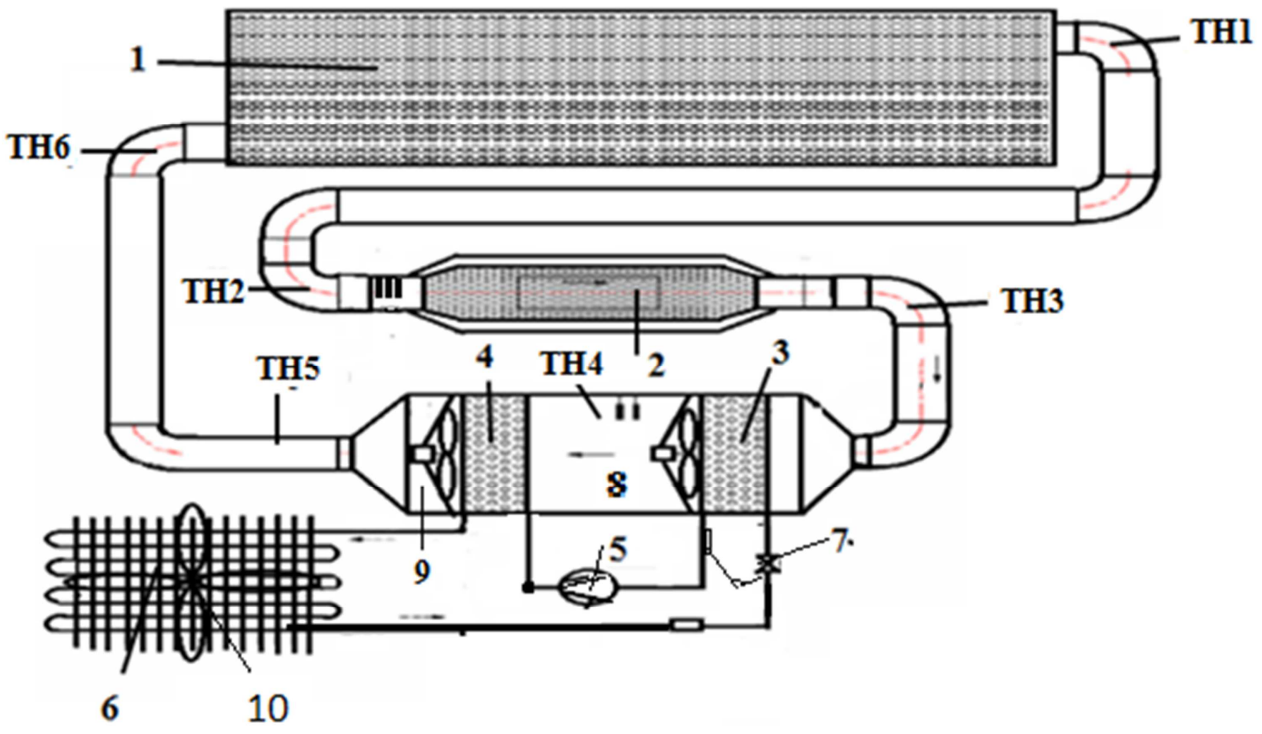

Figure 1. Schematic diagram of the solar-assisted heat pump dryer.

1- flat plate collector; 2- drying chamber; 3- evaporator; 4- main condenser; 5- Compressor; 6- secondary condenser; 7- Expansion valve; 8,9- exhaust fans; $\mathrm{TH}_{1}, \mathrm{TH}_{2}, \mathrm{TH}_{3}, \mathrm{TH}_{4}, \mathrm{TH}_{5}, \mathrm{TH}_{6}$ Temperature- humidity sensors.

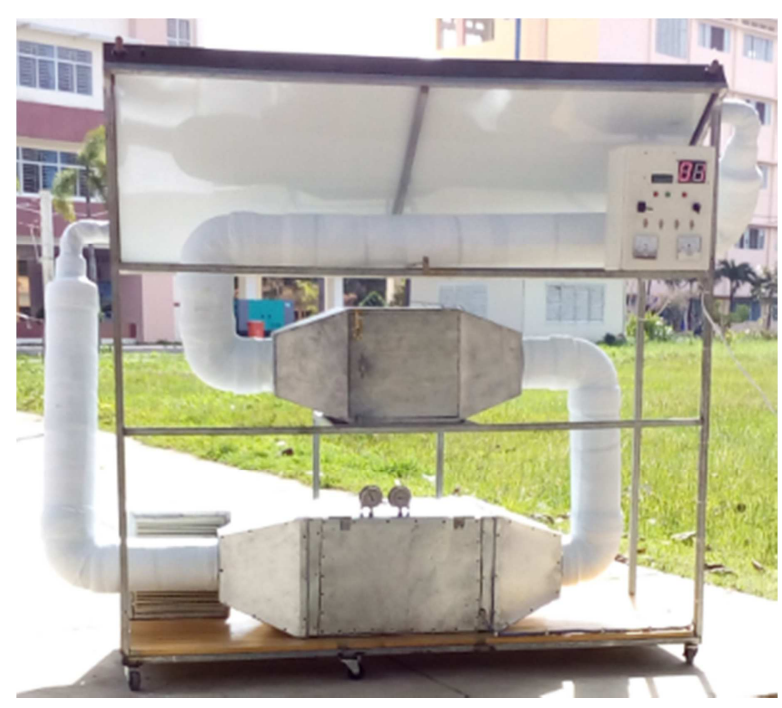

Figure 2. Photograph behind of the solar-assisted heat pump dryer.

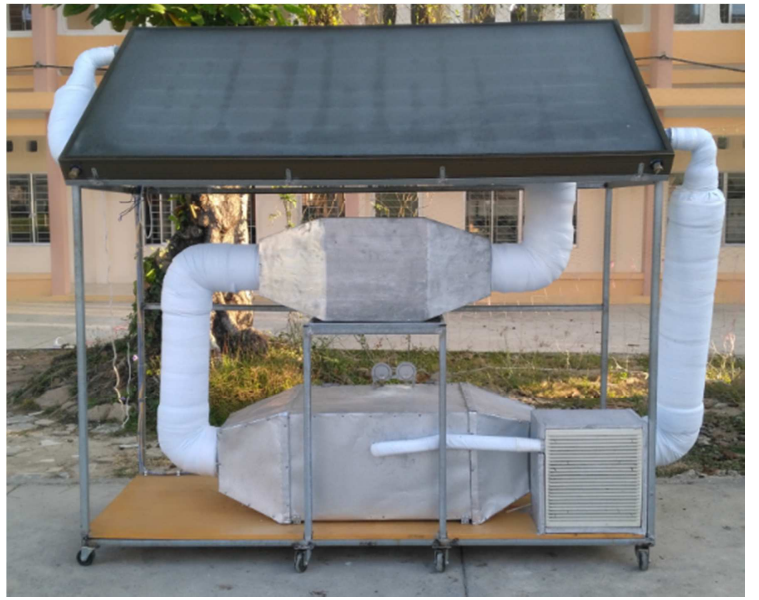

Figure 3. Photograph opposite of the solar-assisted heat pump dryer.

\subsection{Operation Principles}

- When the system is in operation, the air shall be fed by fan 8 through the evaporator 3 for cooling and separating a part of the water vapor from the air. Then air shall be passed 
through condenser 4 for heating and passed through flat plate collector 1 to absorb heat from incoming solar radiation and enter the drying chamber 2 . If solar radiation is insufficient to maintain pre-set heat value in the drying chamber, then the resistant bars shall be switched on to heat the heat pump. Once the solar radiation received by the collector is sufficient to maintain the temperature in the drying chamber, they shall be turned off.

- During the drying process, the heat pump works continuously. In the refrigerant cycle, the refrigerant is compressed by the compressor 5 and compressed to high pressure and enters the condenser. In the condenser, a part of the heat is discharged to the ambient environment at auxiliary condenser 6 , and other part is for heating the air at the main condenser 4. Refrigerant vapor from the condenser is in the liquid state and goes to the expansion valve 7 to reduce its pressure, low pressure liquid refrigerant will be injected into the evaporator 3 to collect the heat of the drying agent. The cycle is repeatedly closed to perform the air treatment in the drying system.

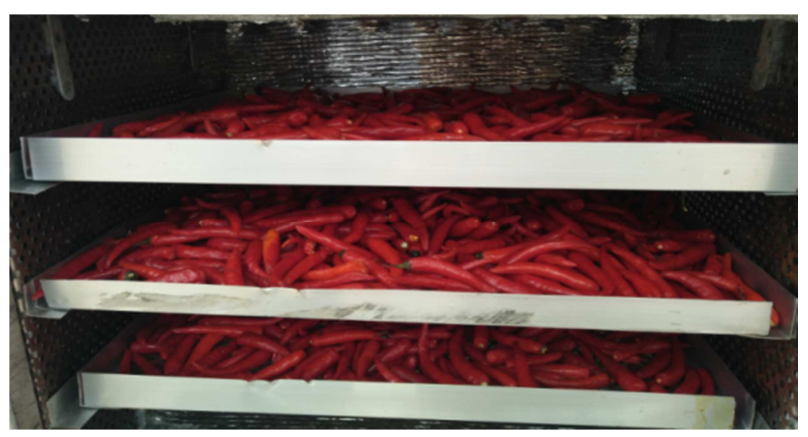

Figure 4. Photograph of the drying chamber.

\subsection{Experimental Method}

The experiment was conducted at Vinh Long University of Technology Education. The parameters to be collected during the measurement include: solar radiation, power consumption, ambient temperature and humidity, temperature and humidity at the inlet and outlet of the solar energy collector, drying chamber and condenser for air heating. Chili is washed with clean water to remove microorganisms and dirt, and then blanched with hot water to produce chemical and physiological changes which are favorable for drying. Then it is placed in the tray with size of $38 \mathrm{~cm} \mathrm{x} 40 \mathrm{~cm}$ in dimension and put into the drying chamber. Chili weight for each test is $5 \mathrm{~kg}$. The experiment was carried out at a temperature of $55^{\circ} \mathrm{C}$. Each experiment is started at 4 am and the drying process was carried out from chili's initial water content until its water content of $11 \%$. To determine the initial water content of chili, we used a high temperature drying cabinet to dry it at $300^{\circ} \mathrm{C}$, until its weight unchanged. So we can find evaporated water content and determine the initial water content of chili. After every 30 minutes, the chili trays shall be drawn out and weighted by an electronic scale to determine the weight loss of chili. The temperature, humidity and radiation parameters shall be determined every 15 minutes. Data will be recorded and processed by Excel program. To evaluate the effectiveness of the system, the experiments were conducted under different weather conditions including a clear day, an intermittent cloud sky day and an overcast sky day.

\section{Results and Discussion}

The figure 5 and 6 show the operation of the dryer on a clear day. The average daylight time is approximately 10 hours per day. The average radiation in the period from 7 am to $5 \mathrm{pm}$ is of $547.3 \mathrm{~W} / \mathrm{m}^{2}$. Radiation is highest at about 13 o'clock with radiant intensity of $1090 \mathrm{~W} / \mathrm{m}^{2}$. During drying, the chili weight is decreased from $5 \mathrm{~kg}$ to $1.48 \mathrm{~kg}$ and it takes 21 hours for drying. Total useful energy generated by the collector during the daytime sunshine is of $14.5 \mathrm{~kW}$. Power consumption for the entire drying process is of $19.2 \mathrm{kWh}$ including power consumption of resistant bars, heat pumps and exhausted fans.

Figure 6 shows the change in COP as well as the temperature of the air before and after the condenser. The COP of the heat pump during drying period in the clear day is in the range of 3.15 to 3.59 with an average value of 3.45 .

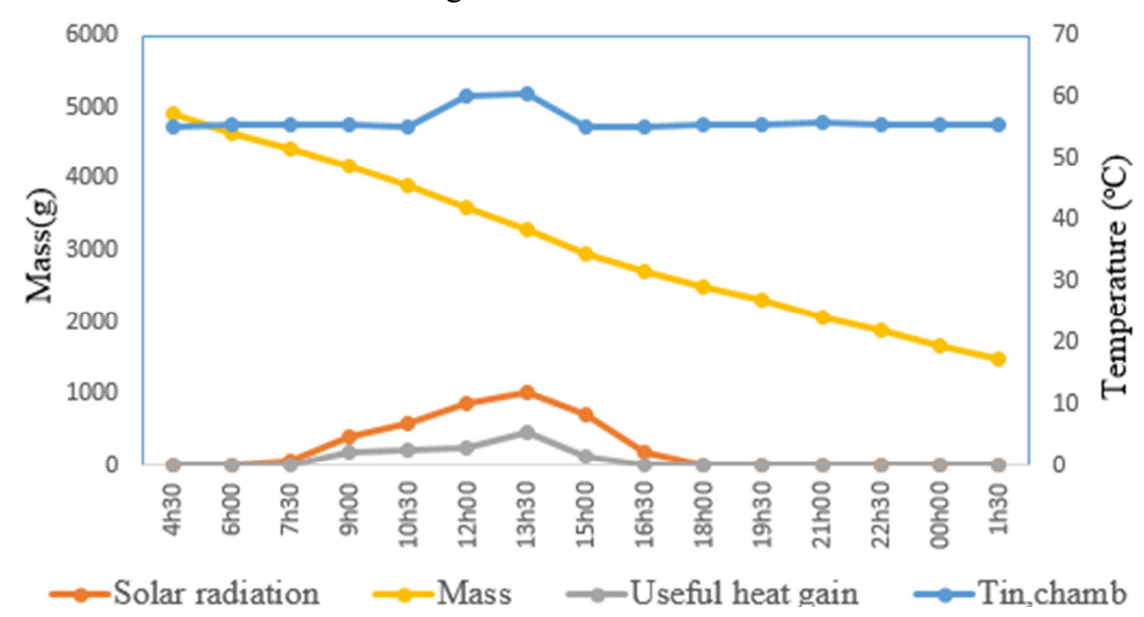

Figure 5. Variation in solar radiation, useful heat again and mass versus drying time in clear day. 


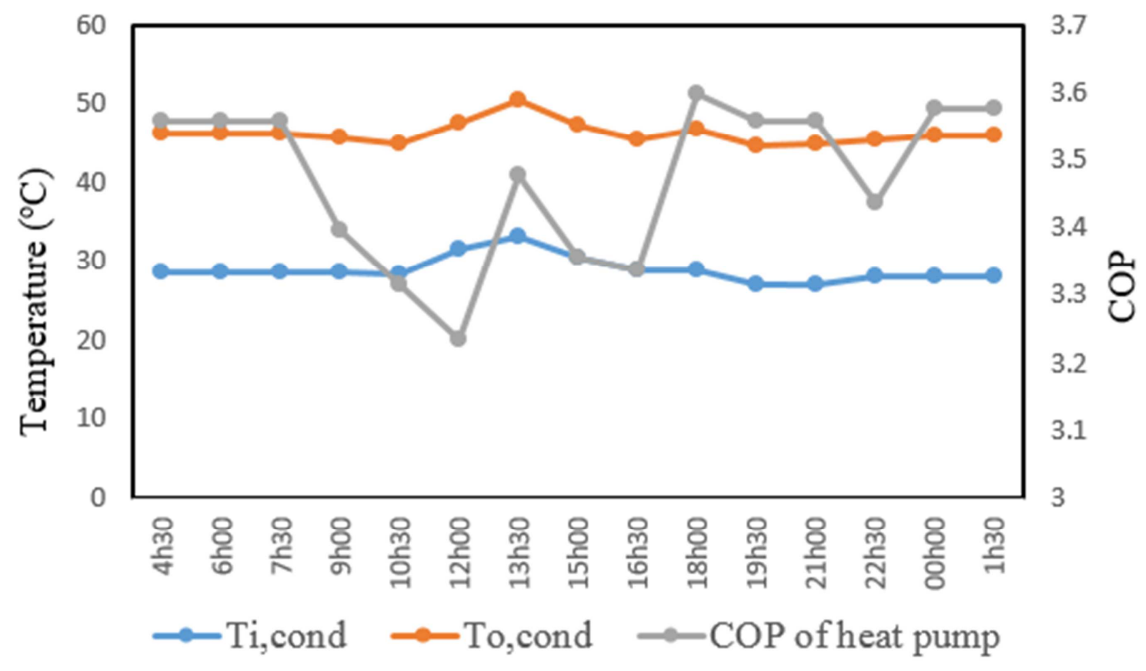

Figure 6. Variation in COP versus drying time in clear day.

Figure 7 and 8 show the operation of the dryer under heavy cloud conditions. During drying, the chili weight is decreased from $5 \mathrm{~kg}$ to $1.52 \mathrm{~kg}$, and it takes 22 hours 30 minutes for drying. The average radiation in the period from $7 \mathrm{am}$ to $5 \mathrm{pm}$ is of $279.5 \mathrm{~W} / \mathrm{m}^{2}$. Total useful energy generated by the collector during the intermittent cloud sky day is of $8.91 \mathrm{~kW}$. Power consumption for the entire drying process is of $21.4 \mathrm{~kW}$ including power consumption of resistant bars, heat pumps and exhausted fans.

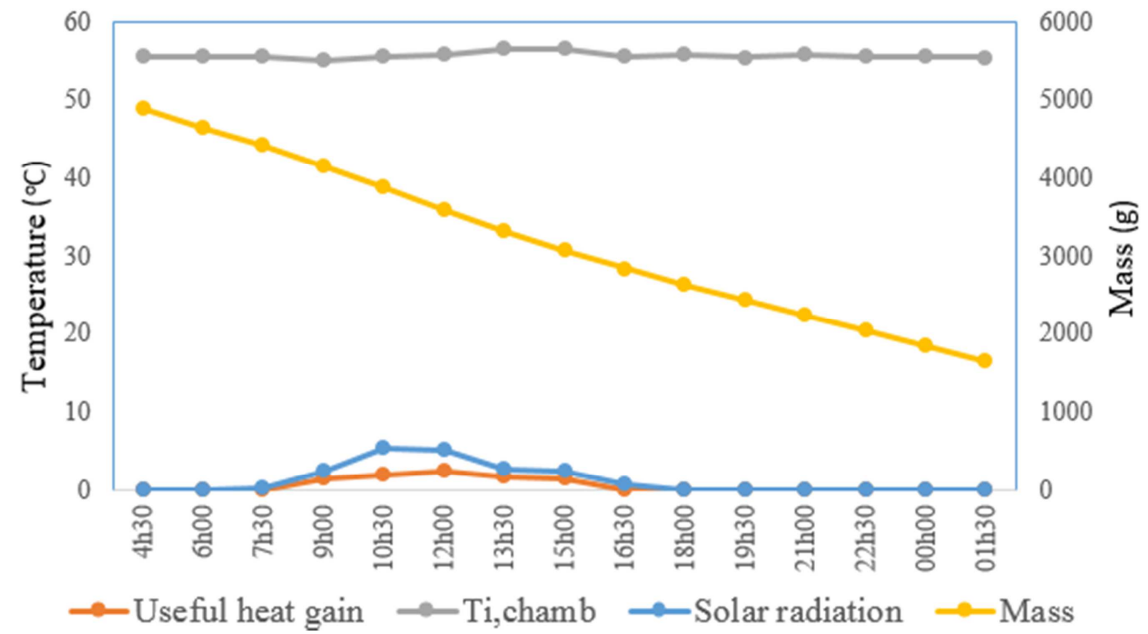

Figure 7. Variation in solar radiation, useful heat again and mass versus drying time in intermittent cloud sky day.

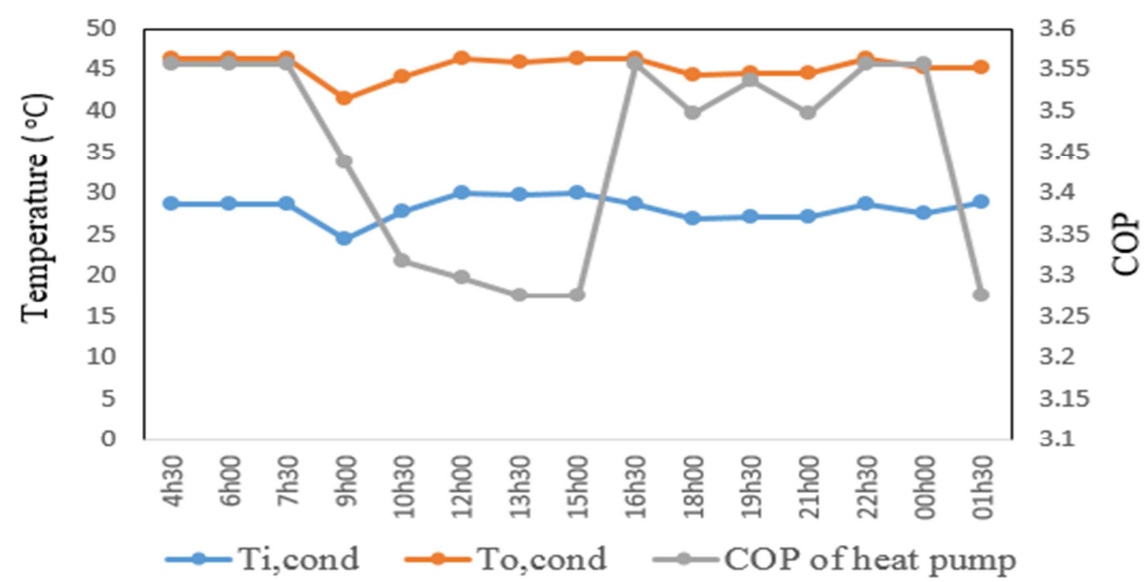

Figure 8. Variation in COP versus drying time in intermittent cloud sky day.

Figure 8 also shows the change in $\mathrm{COP}$ as well as the temperature of the air before and after the condenser. COP of 
the heat pump during the drying time of the intermittent cloud sky day is in the range of 3.21 to 3.63 , with an average value of 3.46 .

Figure 9 and 10 show the operation of the dryer in rainy and non-sunny conditions for whole day. In such weather conditions, the radiation collected during the day is of 79.8 $\mathrm{W} / \mathrm{m}^{2}$, due to low radiation, flat panel collector is failure to generate useful energy. During the drying process, the chili weight is decreased from $5 \mathrm{~kg}$ to $1.535 \mathrm{~kg}$ and it takes 23 hours for drying. Power consumption for the entire drying process is of $26.1 \mathrm{kWh}$. Figure 10 shows the change in COP as well as the temperature of the drying agent before and after the condenser. COP of the heat pump during the drying time of the overcast sky day is from 3.33 to 3.61 with average value of 3.51

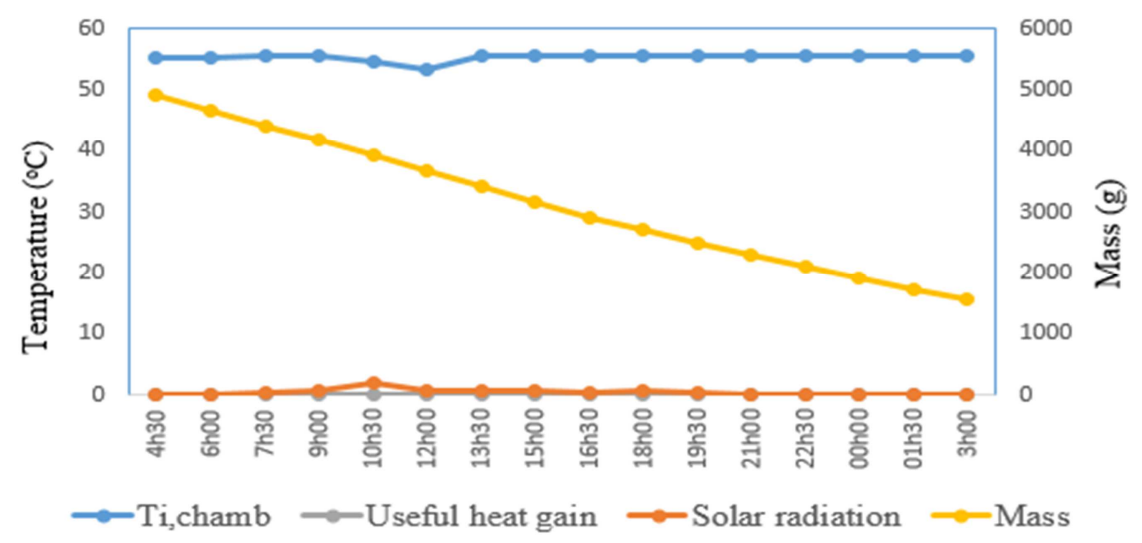

Figure 9. Variation in solar radiation, useful heat again and mass versus drying time in overcast sky day.

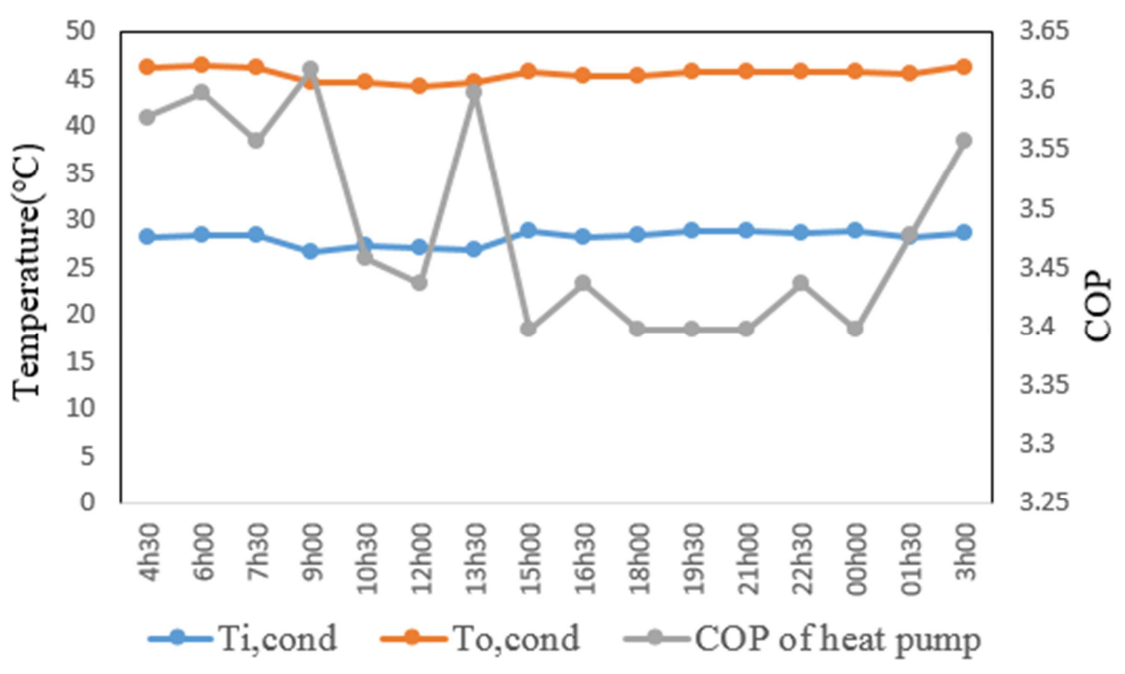

Figure 10. Variation in COP versus drying time in overcast sky day.

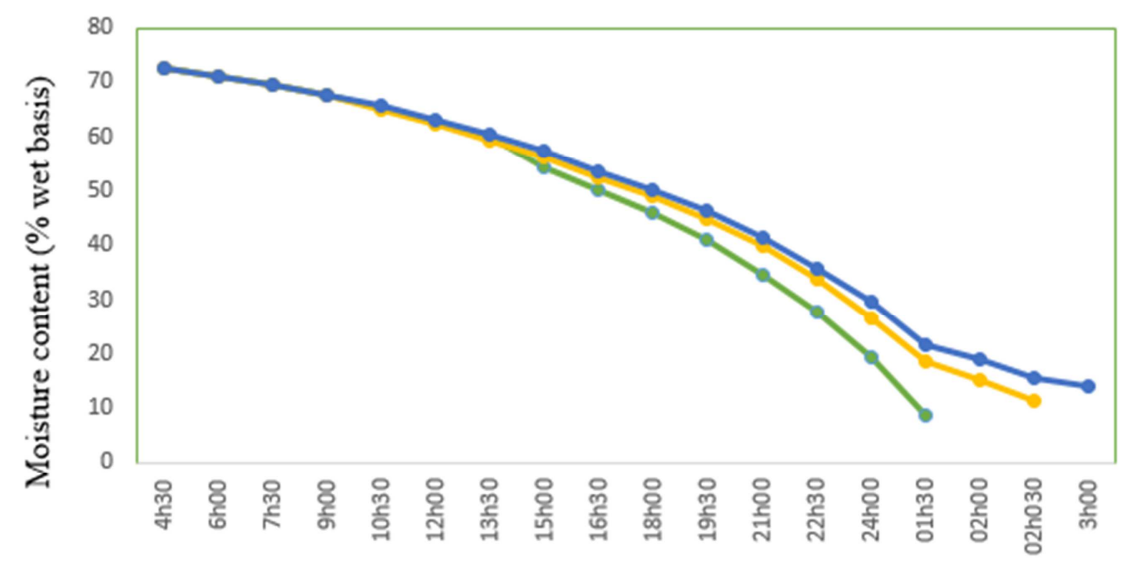

$\multimap$ Clear day $\multimap$ intermittent cloud sky day $\multimap$ Overcast sky day

Figure 11. Variation in COP versus drying time in overcast sky day. 
Figure 11 shows the moisture content of chili is changed over time in the experiments. The findings showed that on sunny days, the drying time from the initial moisture content until the moisture of $11 \%$ is faster than the two other experiments. For the period from drying commencement to 7 hours 30 minutes, chili's water content change is almost equal in all 3 experiments. However, after this time point, its moisture in the overcast sky day is tended to decrease more slowly than in the other two experiments. At about 13 o'clock, its moisture content in sunny days is rapidly decreased. It is also the time when solar radiation energy is very high.

\section{Conclusions}

The experiments were carried out in three different weather conditions: clear day, intermittent cloud sky day and overcast sky day to evaluate the performance of the heatpump combined solar energy dryer in drying chili. From the findings of such experiments, it was found that drying in sunny days saves time and electricity consumption more than in cloudy or rainy days. The findings also showed that the useful energy generated by the collector in clear day, intermittent cloud sky day and overcast sky day are of 14.5 $\mathrm{kWh} ; 8.91 \mathrm{kWh}$; and $0 \mathrm{kWh}$, respectively and power consumption for the above cases is of $19.2 \mathrm{kWh}, 21.4 \mathrm{kWh}$, and $26.1 \mathrm{kWh}$, respectively. The COP of heat pump for the three cases are of $3.45 ; 3.46$; and 3.51 , respectively.

Although manufactured solar energy and heat pump drying system has not been perfect as same as our original calculations yet, the initial findings show that this is a drying method which is completely able to be applied in the climatic conditions of Vietnam. This is also the premise for new researches to put the method of heat-pump combined solar energy drying into deployment in practical production.

\section{Nomenclature}

$A c$ : area of the collector $\left(\mathrm{m}^{2}\right)$

Cpair: specific heat of air $\left(\mathrm{J} \mathrm{kg}^{-1 \circ} \mathrm{C}^{-1}\right)$

$\mathrm{Eb}$ : electrical energy consumed by the blower $(\mathrm{kW})$

$(\mathrm{kW})$

Ecomp: electrical energy consumed by the compressor

Einput: energy input to the drying system $(\mathrm{kW})$

Eevap: energy used for moisture evaporation $(\mathrm{kW})$

ER,Cond: Thermal energy released by the condenser $(\mathrm{kW})$

Es: energy incident in the plane of the solar collector $(\mathrm{kW})$

EUcoll: useful heat gain by the solar collector $(\mathrm{kW})$

Hfg: latent heat $\left({ }^{\circ} \mathrm{C}\right)$

$I_{t}$ : solar radiation $\left(\mathrm{W} / \mathrm{m}^{2}\right)$

$M c$ : moisture content $(\%)$

$M f$ : final moisture content (\%)

$M i$ : initial moisture content (\%)

$m p$ : initial mass of the product $(\mathrm{kg})$

$m d$ : mass of the bone dry $(\mathrm{kg})$

$m_{W}$ : mass of water $(\mathrm{kg})$ $m_{\text {Water }}:$ mass of water evaporated $(\mathrm{kg})$

$\dot{m}_{\text {air }}$ : air mass flow rate $(\mathrm{kg} / \mathrm{s})$

$\dot{m}_{d a}$ mass flow rate of dry air $(\mathrm{kg} / \mathrm{s})$

$\dot{m}_{\text {water }}$ : drying rate $(\mathrm{kg} / \mathrm{s})$

$\mathrm{T}_{\mathrm{i}, \text { chamb }}$ : air temperatures at the inlet of the chamber $\left({ }^{\circ} \mathrm{C}\right)$

$\mathrm{T}_{\mathrm{o} \text {,chamb }}$ : air temperatures at the outlet of the chamber $\left({ }^{\circ} \mathrm{C}\right)$

$\mathrm{T}_{\mathrm{i}, \text { cond }}$ : air temperatures at the inlet of the condenser $\left({ }^{\circ} \mathrm{C}\right)$

$\mathrm{T}_{\mathrm{o} \text {,cond }}$ : air temperatures at the outlet of the condenser $\left({ }^{\circ} \mathrm{C}\right)$

$S F$ solar fraction

SMER specific moisture extraction rate

COP coefficients of performance

\section{References}

[1] Fudholi, A., Sopian, K., Bakhtyar, B., Gabbasa, M., Othman, M. Y., Ruslan, M. H., 2015b. Review of solar drying systems with air-based solar collectors in Malaysia. Renew. Sustain. Energy Rev. 51, 1191-1204.

[2] M. Yahya, Ahmad Fudholi, Hadyan Hafizh, Kamaruzzaman Sopian. Comparison of solar and solar asisted heat pump dryer.

[3] Mohammed Ayub Hossaina, Klaus Gottschalkb, Mohammad Shoeb Hassanc, Mathematical model for a heat pump dryer for aromatic plant, Procedia Engineering 56 (2013) 510-520.

[4] Daghigh, R., Ruslan, M. H., Sulaiman, M. Y., Sopian, K., 2010. Review of solar assisted heat pump drying systems for agricultural and marine products. Renew. Sustain. Energy Rev $14,2564-2579$.

[5] Fudholi, A., Sopian, K., Gabbasa, M., Bakhtyar, B., Yahya, M., Ruslan, M. H., Mat, S. 2015a. Techno-economic of solar drying systems with water based solar collectors in Malaysia: a review. Renew. Sustain. Energy Rev. 51, 809-820.

[6] Bala, B. K., Janjai, S., 2012. Solar drying technology: potentials and developments. Energy Environ. Sustain. Develop, 69-98.

[7] Fudholi, A., Sopian, K., Alghoul, M. A., Ruslan, M. H., Othman, M. Y., 2015c. Performances and improvement potential of solar drying system for palm oil fronds. Renew. Energy 78, 561-565.

[8] Fudholi, A., Sopian, K., Yazdi, M. H., Ruslan, M. H., Gabbasa, M., Kazem, H. A., 2014a. Performance analysis of solar drying system for red chili. Sol. Energy 99, 47-54.

[9] Fudholi, A., Sopian, K., Othman, M. Y., Ruslan, M. H., 2014b. Energy and exergy analyses of solar drying system for red seaweed. Energy Build. 68, 121-129. Solar Energy 136 (2016) 606-613.

[10] Bala, B. K., Mondal, M. R. A., 2001. Experimental investigation of solar drying of fishusing solar tunnel drier. Drying Technol. 19 (2), 1-10.

[11] Fudholi, A., Othman, M. Y., Ruslan, M. H., Sopian, K., 2013. Drying of Malaysian Capsicum annuum L. (red chili) dried by open and solar drying. Int. J. Photoenergy, 1-9.

[12] Ghaba, P., Andoh, H. Y., Saraka, J. K., Koua, B. K., Toure, S., 2007. Experimental investigation of a solar dryer with natural convective heat flow. Renew. Energy 32, 1817-1829. 
[13] Goh, L. J., Othman, M. Y., Mat, S., Ruslan, M. H., Sopian, K., 2011. Review of heat pump systems for drying application. Renew. Sustain. Energy Rev. 15, 4788-4796.

[14] Hossain, M. A., Bala, B. K., 2007. Design of hot chilli using solar tunnel drier. Sol. Energy 81, 85-92.

[15] Hossain, M. A., Woods, J. L., Bala, B. K., 2005. Optimization of solar tunnel drier for drying of chilli without color loss. Renew. Energy 30, 729-742.

[16] Janjai, S., Lamlert, N., Intawee, P., Mahayothee, B., Bala, B. K., Nagle, M., Muller, J. E., 2009. Experimental and simulated performance of a PV-ventolated solar greenhouse dryer for drying of peeled longan and banana. Sol. Energy 83, $1550-1565$.

[17] Janjai, S., Srisitipokakun, N., Bala, B. K., 2008. Experimental and modelling performances of aroof-integrated solar drying system for drying herbs and spices. Energy 33, 91-103.

[18] Janjai, S., Tung, P., 2005. Performance of a solar dryer using hot air from roofintegrated solar collector for drying herbs and spices. Renew. Energy 30, 2085-2095.

[19] Kaewkiew, J., Nabneaan, S., Janjai, S., 2012. Experimental investigation of the performance of a large-scale greenhouse type solar dryer for drying chilli in Thailand. Procedia Eng. $32,433-439$.

[20] Mohanraj, M., Chandrasekar, P., 2009. Performance of a forced convection solar drier integrated with gravel as heat storage material for chili drying. J. Eng. Sci. Technol. 4 (3), 305-314.

[21] Purohit, P., Kumar, A., Kandpal, T. C., 2006. Solar drying vs. Open sun drying: a framework for financial evaluation. Sol. Energy 80, 1568-1579.

[22] Banout, J., Ehl, P., Havlik, J., Lojka, B., Polesny, Z., Verner, V., 2011. Design and performance evaluation of a double-pass solar drier for drying of red chilli (Capsicum annuum L.). Sol. Energy 85, 506-525. 